\begin{tabular}{|c|c|}
\hline Title & A high-temperature in situ cell with a large solid angle for fluorescence X-ray absorption fine structure measurement \\
\hline Author(s) & $\begin{array}{l}\text { Murata, Naoyoshi; Kobay ashi, Makoto; Okada, Y ukari; Suzuki, Takuya; Nitani, Hiroaki; Niwa, Y asuhiro; A be, Hitoshi; } \\
\text { Wada, T akahiro; Mukai, Shingo; U ehara, Hiromitsu; A riga, Hiroko; T akakusagi, Satoru; A sakura, Kiyotaka }\end{array}$ \\
\hline Citation & $\begin{array}{l}\text { Review of scientific instruments, 86(3), 034102-1-034102-6 } \\
\text { https://doi.org/10.1063/1.4914459 }\end{array}$ \\
\hline Issue Date & 2015-03 \\
\hline Doc URL & http:/hdl.handle.net/2115/59168 \\
\hline Rights & $\begin{array}{l}\text { Copyright } 2015 \text { A merican Institute of Physics. This article may be downloaded for personal use only. A ny other use } \\
\text { requires prior permission of the author and the A merican Institute of Physics. The following article appeared in Review } \\
\text { of Scientific Instruments and may be found at http://scitation.aip.org/content/aip/ournal/ssi } / 86 / 10.1063 / 1.4914459\end{array}$ \\
\hline Type & article \\
\hline File Information & 1.4914459.pdf \\
\hline
\end{tabular}

Instructions for use 


\section{AIP | Rateren of}

\section{A high-temperature in situ cell with a large solid angle for fluorescence X-ray absorption fine structure measurement}

Naoyoshi Murata, Makoto Kobayashi, Yukari Okada, Takuya Suzuki, Hiroaki Nitani, Yasuhiro Niwa, Hitoshi Abe, Takahiro Wada, Shingo Mukai, Hiromitsu Uehara, Hiroko Ariga, Satoru Takakusagi, and Kiyotaka Asakura

Citation: Review of Scientific Instruments 86, 034102 (2015); doi: 10.1063/1.4914459

View online: $\mathrm{http} / / / \mathrm{dx}$. doi.org/10.1063/1.4914459

View Table of Contents: http://scitation.aip.org/content/aip/journal/rsi/86/3?ver=pdfcov

Published by the AIP Publishing

\section{Articles you may be interested in}

Versatile plug flow catalytic cell for in situ transmission/fluorescence $x$-ray absorption fine structure measurements

Rev. Sci. Instrum. 84, 054102 (2013); 10.1063/1.4807287

Note: Construction of $x$-ray scattering and $x$-ray absorption fine structure beamline at the Pohang Light

\section{Source}

Rev. Sci. Instrum. 81, 026103 (2010); 10.1063/1.3298581

Design of a high-temperature and high-pressure liquid flow cell for x-ray absorption fine structure measurements under catalytic reaction conditions

Rev. Sci. Instrum. 79, 014101 (2008); 10.1063/1.2829156

High-pressure, high-temperature x-ray absorption fine structure transmission cell for the study of aqueous ions with low absorption-edge energies

Rev. Sci. Instrum. 75, 5228 (2004); 10.1063/1.1813131

Log spiral of revolution highly oriented pyrolytic graphite monochromator for fluorescence x-ray absorption edge fine structure

Rev. Sci. Instrum. 71, 3267 (2000); 10.1063/1.1287753

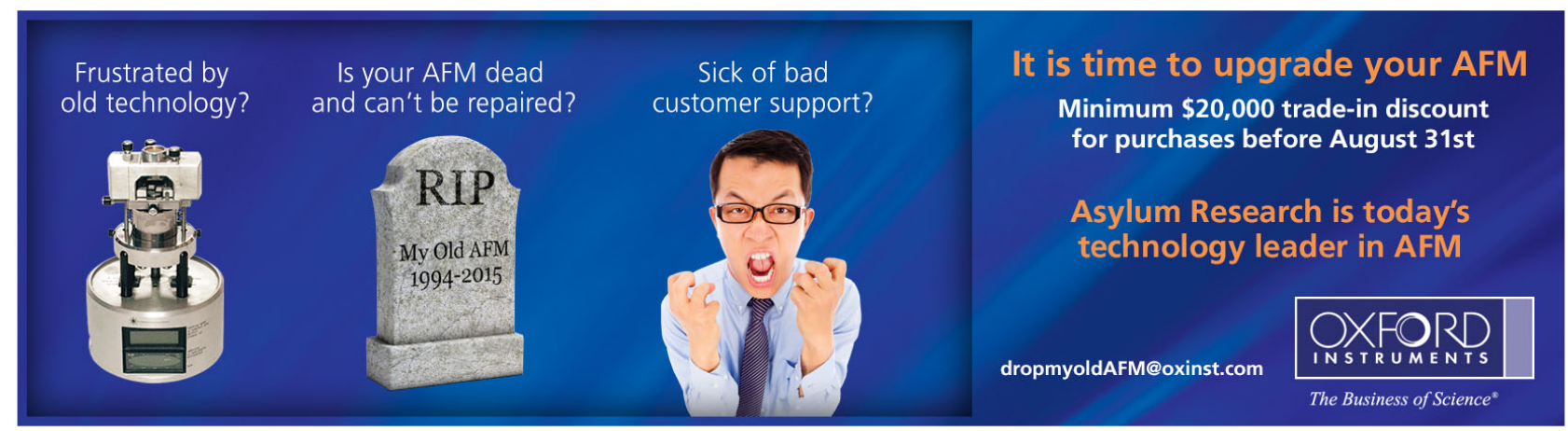




\title{
A high-temperature in situ cell with a large solid angle for fluorescence X-ray absorption fine structure measurement
}

\author{
Naoyoshi Murata,,${ }^{1,2}$ Makoto Kobayashi, ${ }^{1}$ Yukari Okada, ${ }^{1}$ Takuya Suzuki, ${ }^{1}$ Hiroaki Nitani, ${ }^{3}$ \\ Yasuhiro Niwa, ${ }^{3}$ Hitoshi Abe, ${ }^{3}$ Takahiro Wada, ${ }^{4}$ Shingo Mukai, ${ }^{5}$ Hiromitsu Uehara, ${ }^{5}$ \\ Hiroko Ariga, ${ }^{5}$ Satoru Takakusagi, ${ }^{5}$ and Kiyotaka Asakura ${ }^{5}$ \\ ${ }^{1}$ Corporate $R \mathcal{E}$ D Headquarters, Fuji Electric Co., Ltd., Tokyo 191-8502, Japan \\ ${ }^{2}$ Department of Quantum Science and Engineering, Graduate School of Engineering, Hokkaido University, \\ Sapporo 001-0021, Japan \\ ${ }^{3}$ Photon Factory, Institute of Materials Structure Science, High Energy Accelerator Research Organization \\ (KEK-PF), Tsukuba 305-0811, Japan \\ ${ }^{4}$ Department of Advanced Biomaterials, Graduate School of Medical and Dental Sciences, Tokyo Medical \\ and Dental University, Tokyo 113-8549, Japan \\ ${ }^{5}$ Catalysis Research Center, Hokkaido University, Sapporo 001-0021, Japan
}

(Received 2 September 2014; accepted 26 February 2015; published online 31 March 2015)

\begin{abstract}
We present the design and performance of a high-temperature in situ cell with a large solid angle for fluorescence X-ray absorption fine structure (XAFS) spectra. The cell has a large fluorescence XAFS window $\left(116 \mathrm{~mm}^{\phi}\right)$ near the sample in the cell, realizing a large half-cone angle of $56^{\circ}$. We use a small heater $\left(25 \times 35 \mathrm{~mm}^{2}\right)$ to heat the sample locally to $873 \mathrm{~K}$. We measured a Pt-SnO $\mathrm{Shin}$ layer on a Si substrate at reaction conditions having a high activity. In situ measurement enables the analysis of the difference XAFS spectra between before and during the reaction to reveal the structure change during the operation. (C) 2015 AIP Publishing LLC. [http://dx.doi.org/10.1063/1.4914459]
\end{abstract}

\section{INTRODUCTION}

Fluorescence X-ray absorption fine structure (XAFS) is a powerful technique for determining the local structure in a dilute system. ${ }^{1,2}$ When X-ray absorption occurs with the core electron emission as a photoelectron, the created core hole is filled by a transition from the outer shell electrons accompanied with an emission of a fluorescence X-ray. Consequently, if the sample is dilute or in a thin film, the fluorescence X-ray intensity becomes proportional to the absorption coefficient. Because the fluorescence X-ray emission occurs in a $4 \pi \mathrm{sr}$, the use of a large solid-angle detector, such as a multielement solid state detector $(\mathrm{SSD})^{3}$ or a Lytle detector, ${ }^{4}$ is desirable. Recently, a crystal monochromator is used to detect fluorescence XAFS which improves the detection limit and an energy resolution. ${ }^{5-9}$

The strong penetration power of an X-ray allows investigators to perform in situ XAFS measurement under reaction conditions to reveal catalytic mechanisms. ${ }^{10}$ Numerous in situ fluorescence XAFS experiments have been performed on the systems of fuel cell, corrosion, catalyst, and gas sensors. ${ }^{5,6,11-29}$ In situ fluorescence XAFS cells require a large fluorescence window at a position sufficiently close to the sample to secure a large solid angle. When the polymer window is used for the in situ fluorescence XAFS measurements, it is difficult to realize the large solid angle because the fluorescence window temperature raises easily even if the peripheral region of the window is cooled by water flow owing to low thermal conductivity of polymer window material. Kappen and Grunwaldt et al. used a thin quartz tube as an incident and fluorescence $\mathrm{X}$-ray window ${ }^{7,8}$ where the quartz window can be in contact with the sample because the quartz window is a temperature proof material. Another alternative is to decrease the power supply by decreasing the sample size. High-brilliance synchrotron radiation is now available, and the X-ray can be focused to an area less than a few $\mathrm{mm}^{2}$ for the small samples to be used. In this study, we selected this option so that the distance between the window and the heater could be as short as $35 \mathrm{~mm}$. The window temperature reached only $373 \mathrm{~K}$ without any cooling, even when the sample was heated to $703 \mathrm{~K}$. The cell used in this study enables us to measure the in situ fluorescence XAFS of flat substrate, electrode, large surface area film, and powder samples. In this paper, we measured the fluorescence XAFS spectra of a Pt$\mathrm{SnO}_{2}$ thin film on a $\mathrm{Si}$ substrate as model sensor catalyst under the working conditions.

\section{IN SITU CELL}

\section{A. Structure of the in situ cell}

Figure 1 shows a photograph and schematic sketches of the in situ cell. To install the cell more easily at any beam line, the cell body was made of aluminum to increase its portability. The cell weight was just $2.4 \mathrm{~kg}$. In addition, local heating of the cell body could be avoided because of Al's high thermal conductivity. The volume of the cell is about 1.31 in order to keep the volume/sensor area ratio in the same order of the real sensor which was $4 \times 10^{3} \mathrm{~cm}$ and $1.3 \times 10^{3} \mathrm{~cm}$ for real and model sensors, respectively. The cell body had gas flow ports and an incident X-ray window. We used a 200- $\mu$ m-thick Kapton (DuPont, USA) for the incidence and fluorescence Xray windows, which were fixed to the body using an epoxy adhesive. We made a large fluorescence Kapton window with an area of $116 \mathrm{~mm}^{\phi}$. 
(a)

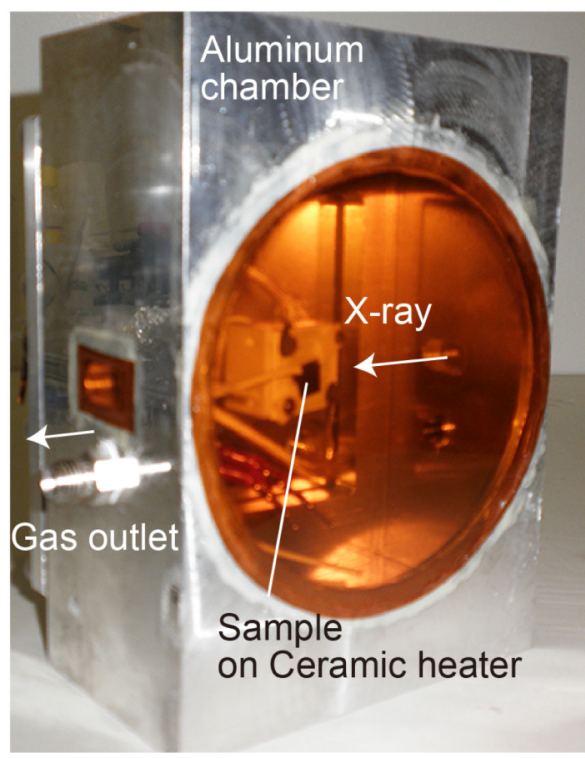

(b)

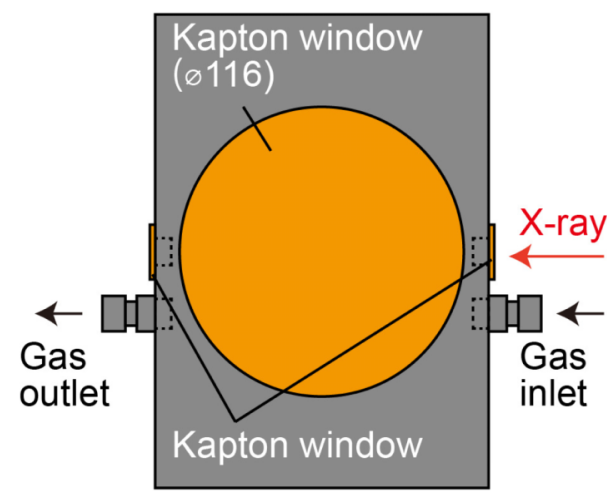

(c)
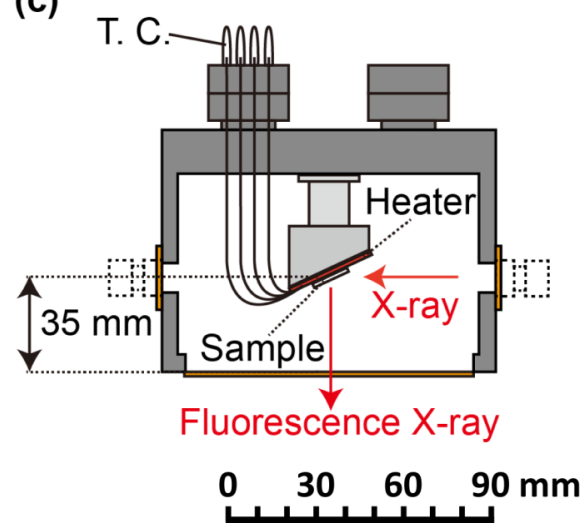

FIG. 1. A photograph and the schematic drawings of the in situ cell. It is (a) photograph, (b) top view, (c) side view.

The cell body had a sample stand with electric feedthroughs for heating the sample. The pyrolytic graphite heater was wrapped with pyrolytic boron nitride (pBN) (HTR1001; Adcap Vacuum Technology Corporation, Japan) and was used to heat the sample to $873 \mathrm{~K}$. The heater size was $25 \mathrm{~mm}^{\phi}$. Temperature was controlled in a proportional-integral-derivative (PID) manner using the temperature controller designed especially by the Sakaguchi Electric Heating Corporation. This temperature controller measured temperature by a chromel-alumel thermocouple attached to the back of the sample. Its temperature sampling time was as short as $25 \mathrm{~ms}$. It controlled the temperature by another chromel-alumel thermocouple attached to the sample holder, as shown in Fig. 2. The heater was fixed to the sample holder. The sample was fixed at two corners with jigs and clinchers to ensure good contact with the heater. The sample holder and jigs were made of $\mathrm{Al}_{2} \mathrm{O}_{3}$ to reduce heat dissipation. The angle between the $\mathrm{X}$-ray direction and the sample stage was set at $25^{\circ}$ as no diffraction from the $\mathrm{Si}$ substrate was detected at this angle empirically. The length from the sample to the window was approximately $35 \mathrm{~mm}$. We did not use a water-cooling system. With this configuration, we can guarantee a large half-cone angle of $56^{\circ}$.

\section{B. XAFS measurements}

We applied this in situ fluorescence XAFS measurement to the characterization of a thin-film catalyst for gas sensor developed on a $\mathrm{Si}$ substrate. $\mathrm{SnO}_{2}$ is a semiconductor whose electric conductivity changes with the existing gas composition. Pt-doped $\mathrm{SnO}_{2}\left(\mathrm{Pt}-\mathrm{SnO}_{2}\right)$ thin film deposited on the $\mathrm{SnO}_{2}$ sensor film shows a high methane sensitivity with a low power consumption and this opens a new way to realize battery-driven gas sensors. ${ }^{30-33}$ Using the fluorescence XAFS to study the local structure of $\mathrm{Pt}$ in this fresh Pt-doped $\mathrm{SnO}_{2}$ film at room temperature, we found that the Pt took a solid solution structure, being located at the $\mathrm{Sn}$ position of the $\mathrm{SnO}_{2}$ lattice. ${ }^{34}$ In literatures, a Pt metal cluster is considered to be an active structure in the reaction. ${ }^{35,36}$ In addition, the structures of catalysts during working conditions are often different from

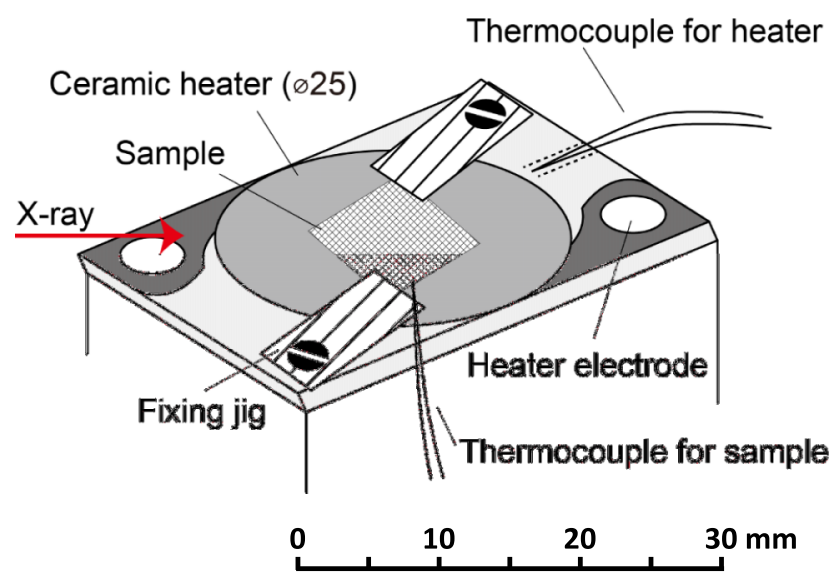

FIG. 2. Sample holder with ceramic heater and thermocouples on the sample stand. 

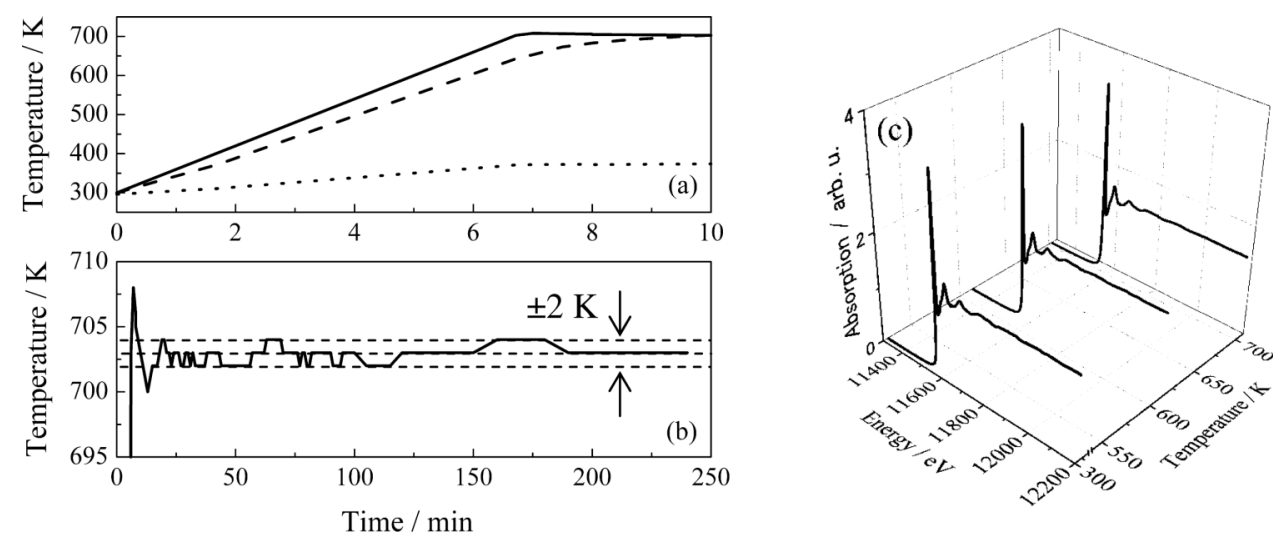

FIG. 3. The heating performance of the cell. (a) The increasing temperature process at the holder (solid line), at the sample (broken line), and at the Kapton window (dotted line). (b) Stability of the temperature for $4 \mathrm{~h}$ at the sample position. (c) XAFS spectra at 303, 613, and $703 \mathrm{~K}$ under the dry air flow.

those existing before the reactions; thus, there is a possibility that the Pt cluster formed during the reaction conditions plays an important role. ${ }^{18,37,38}$ With this in mind, in situ structure analysis is necessary to confirm the actual active structure and reaction mechanism. ${ }^{39-46}$

$\mathrm{Pt}_{\mathrm{L}}$-edge XAFS spectra were measured at an X-ray beam line BL-12C of Photon Factory in Institute for Materials Structure Science, High Energy Accelerator Research Organization (KEK-IMSS-PF) using a Si(111) monochromator in the fluorescence mode. ${ }^{47,48}$ XAFS measurement was performed in $200 \mathrm{ml} / \mathrm{min}$ gas flow. A 19-element SSD was used for the fluorescence detection. XAFS spectra were analyzed with a REX2000 (Version 2.5, Rigaku). ${ }^{49-51}$

Pt-doped $\mathrm{SnO}_{2}$ thin layers of 400-nm thickness were prepared on p-type $\mathrm{Si}$ substrates covered with native $\mathrm{SiO}_{2}$ film $(600 \mathrm{~nm})$ using a sputter-deposition method, followed by annealing at $803 \mathrm{~K}$. The $\mathrm{Pt}$ and $\mathrm{SnO}_{2}$ contents were controlled according to the loading ratio in the targets. The $\mathrm{SnO}_{2}$ thin film was formed by sputter-deposition has column structures composed of a few nm particles. ${ }^{52}$ The final Pt concentrations in the films were determined from films dissolved in hydrochloric acid using inductively coupled plasma (ICP) spectroscopy. The Pt loading was estimated to be 10 at. \% in the Pt$\mathrm{SnO}_{2}$ thin film. ${ }^{31} \mathrm{Pt}-\mathrm{SnO}_{2}$ thin film on a $1 \mathrm{~cm}^{2} \mathrm{Si}$ substrate was loaded in the cell. Judging from the $\mathrm{S} / \mathrm{N}$ ratio of 10 at. \% $\mathrm{Pt} / \mathrm{SnO}_{2}$ thin film, we can measure $1 \times 10^{17} \mathrm{~cm}^{-2}$.

\section{RESULTS AND DISCUSSION}

\section{A. Heating performance}

Although the sample and sample heater in this study were small, the power of the heater and the heat capacity of the sample were sufficiently large for temperature stability. We actually achieved the stable sample temperature using the temperature controller in a current-control mode with welltuned PID parameters. Figure 3 shows the heating performance of the in situ cell. The temperature was linearly raised to $703 \mathrm{~K}$ at the sample position. The sample surface reached this temperature in approximately $3 \mathrm{~min}$, as shown by the dashed line. The temperature overshoot was only $5 \mathrm{~K}$, and the temperature was controlled to within $2 \mathrm{~K}$ for a long time. In the off-line experiment, we measured the fluorescence window temperature at its center by a thermocouple directly attached to the window. Note that the Kapton window was kept at $373 \mathrm{~K}$ because of the small power input, by a dotted line as shown in Fig. 3(a), despite the sample temperature at $703 \mathrm{~K}$. However, the problem was the life of the heater; a very large power supply can readily damage the small heater. Therefore, we installed a safety circuit to prevent the current from being exceeded more than the desired one (5 A). We then slowly increased the power to extend the life for a few days, which was sufficient for one experimental run. Figure 3(c) shows the XAFS spectra at room temperature, $613 \mathrm{~K}$ and $703 \mathrm{~K}$ in dry air flow. We could find little structure change of the Pt local structure at different temperatures.

\section{B. XAFS measurements in and out of the cell}

Figure 4 shows the XAFS spectra of $\mathrm{Pt}-\mathrm{SnO}_{2}$ thin film measured in and out of the cell at room temperature. Both

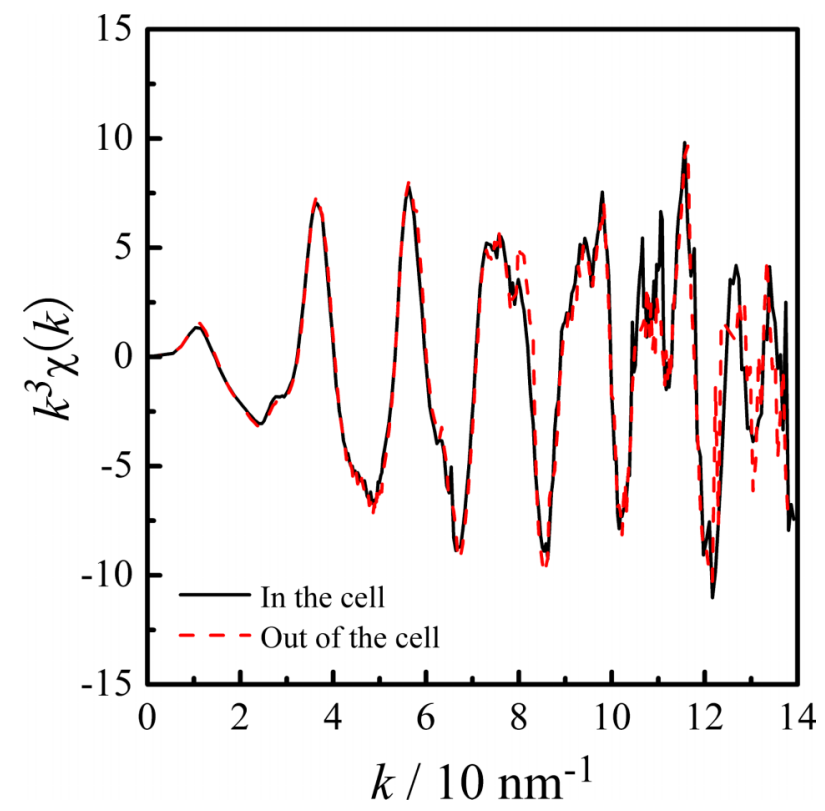

FIG. 4. Comparison of EXAFS oscillation of a Pt-SnO ${ }_{2}$ thin film in the cell (solid line) and out of the cell (broken line) at room temperature. 
spectra were very similar up to $\mathrm{k}=14 \AA^{-1}$. This implies that the data can be accurately analyzed under in situ conditions using this cell. Figure 5 shows X-ray absorption near-edge structure (XANES) spectra measured at the temperature increasing process to $703 \mathrm{~K}$ under a flow of dry air and $1 \% \mathrm{H}_{2}$ containing air (flow rates $=200 \mathrm{ml} / \mathrm{min}$ ). The sensor resistivity was measured in this XAFS measurement cell. Figure 5(b) showed the resistivity at each temperature where XANES spectra were measured as shown Fig. 5(a). There is no difference in sensor resistance when the X-ray beam was on or off. The most reduced state in Pt gave the lowest resistivity. Figure 6 showed XAFS spectra to $703 \mathrm{~K}$ under a flow of dry air and $1 \% \mathrm{H}_{2}$-containing air. We observed small changes in the XANES region in Fig. 6(a). The edge peak (called as white line) decreased when the sample was exposed to the $\mathrm{H}_{2}$-containing air at a high temperature $(703 \mathrm{~K})$. The white line peak was assigned to the $2 \mathrm{p}_{3 / 2} \rightarrow 5 \mathrm{~d}$ transition. ${ }^{53}$ The decrease in the white line peak indicated an increase in the $\mathrm{d}$-electron density of $\mathrm{Pt}$, which was probably because of the loss of the first nearest-neighbor oxygen atoms and/or the formation of Pt nanoparticles. Identifying the change in the original EXAFS oscillation $\left(k^{3} \chi(\mathrm{k})\right)$ was difficult, as shown in Fig. 6(b) so that we calculated its difference before and after contact with the $\mathrm{H}_{2}$-containing air, as shown in Fig. 6(c). The difference EXAFS $\left(k^{3} \Delta \chi(\mathrm{k})\right)$ showed the oscillation clearly. We performed a Fourier transform, as shown in Fig. 7, where one peak appeared at $0.18 \mathrm{~nm}$, corresponding well with Pt-O. This does not necessarily mean that there was an increase in the Pt-O coordination because Fig. 7 shows only the absolute part of the Fourier transform, which does not contain phase information. Figure 8 shows the imaginary and real parts of the Fourier transform of $k^{3} \Delta \chi(\mathrm{k})$ together with the absolute part for the $\mathrm{Pt}-\mathrm{SnO}_{2}$ in dry air at $703 \mathrm{~K}$. Compared with the imaginary parts, the phase of the $\mathrm{Pt}-\mathrm{SnO}_{2}$ peak in Fourier transform of $k^{3} \Delta \chi(\mathrm{k})$ was $\pi$ rad different from the $\mathrm{Pt}-\mathrm{SnO}_{2}$ before the $\mathrm{H}_{2}$-containing air flow, indicating a decrease in the main oscillation arising from $\mathrm{Pt}-\mathrm{O}$. We did not find any notable peak above a noise level in the range of $0.2-0.3 \mathrm{~nm}$, which showed little Pt-Pt formation. Thus, we concluded that $\mathrm{Pt}$ metal nanoparticles were not produced with $\mathrm{H}_{2}$-containing air at high temperature, but a partial reduction of Pt ions occurred with the loss of the oxygen maintaining the location at the lattice position of $\mathrm{SnO}_{2}$.

\section{DISCUSSION}

There have been many reports about in situ cells for the fluorescence XAFS. Cells are classified into two types. The first type of cell is a tubular type. The fluorescence X-ray is measured through an incident window made of quartz..$^{7-10}$ These materials are stable at high temperatures and are thus allowed to have direct contact with the sample. This cell type can provide large half-cone angles. Its drawback is the scattered $\mathrm{X}$-rays from the quartz tube, which increases the background.

The second type of cell is the one that has the sample and windows separated from each other. Different X-ray incidence and fluorescence windows are used for X-ray scattering to be largely reduced. When a thin polymer window is applied, the window temperature has to be kept low. As such, the

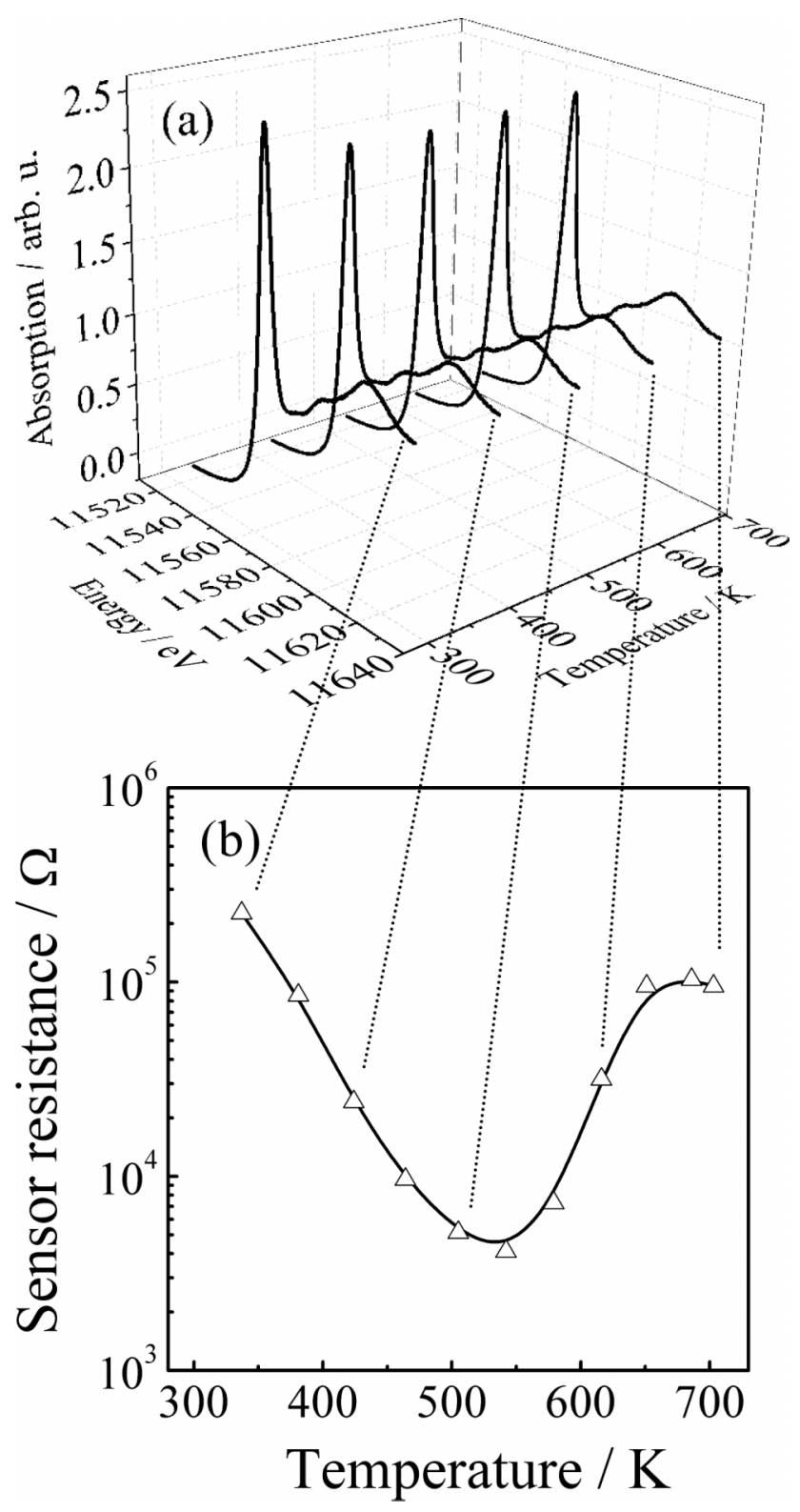

FIG. 5. XANES spectra at the temperature increasing process to $703 \mathrm{~K}$ under a flow of dry air and $1 \% \mathrm{H}_{2}$-containing air (flow rates $=200 \mathrm{ml} / \mathrm{min}$ ) in (a). Sensor property on model sample under the hydrogen based on the dry air flow in (b).

distance between the window and the sample must be long and/or window size is small enough for effective cooling of the window both of which sacrifice a large fluorescence yield. Koziej et al. have reported a XAFS cell for a gas-phase reaction of Pt in Pt-SnO in small heater. ${ }^{13-15}$ Gurlo et al. have reported also another XAFS cell for research of mechanism of sensor with a small integrated heater. ${ }^{16,17}$ Although the samples can be heated effectively keeping the large cone angle for the fluorescence XAFS using these cells, the measurements were limited to those systems with samples that could have a built-in or an integrated heater. In this paper, we used a small sample and a small separate heater. Consequently, the window is not heated up, even with its large window size $\left(116 \mathrm{~mm}^{\phi}\right)$ at a close distance (approximately $35 \mathrm{~mm}$ ). As a result, we have had a 

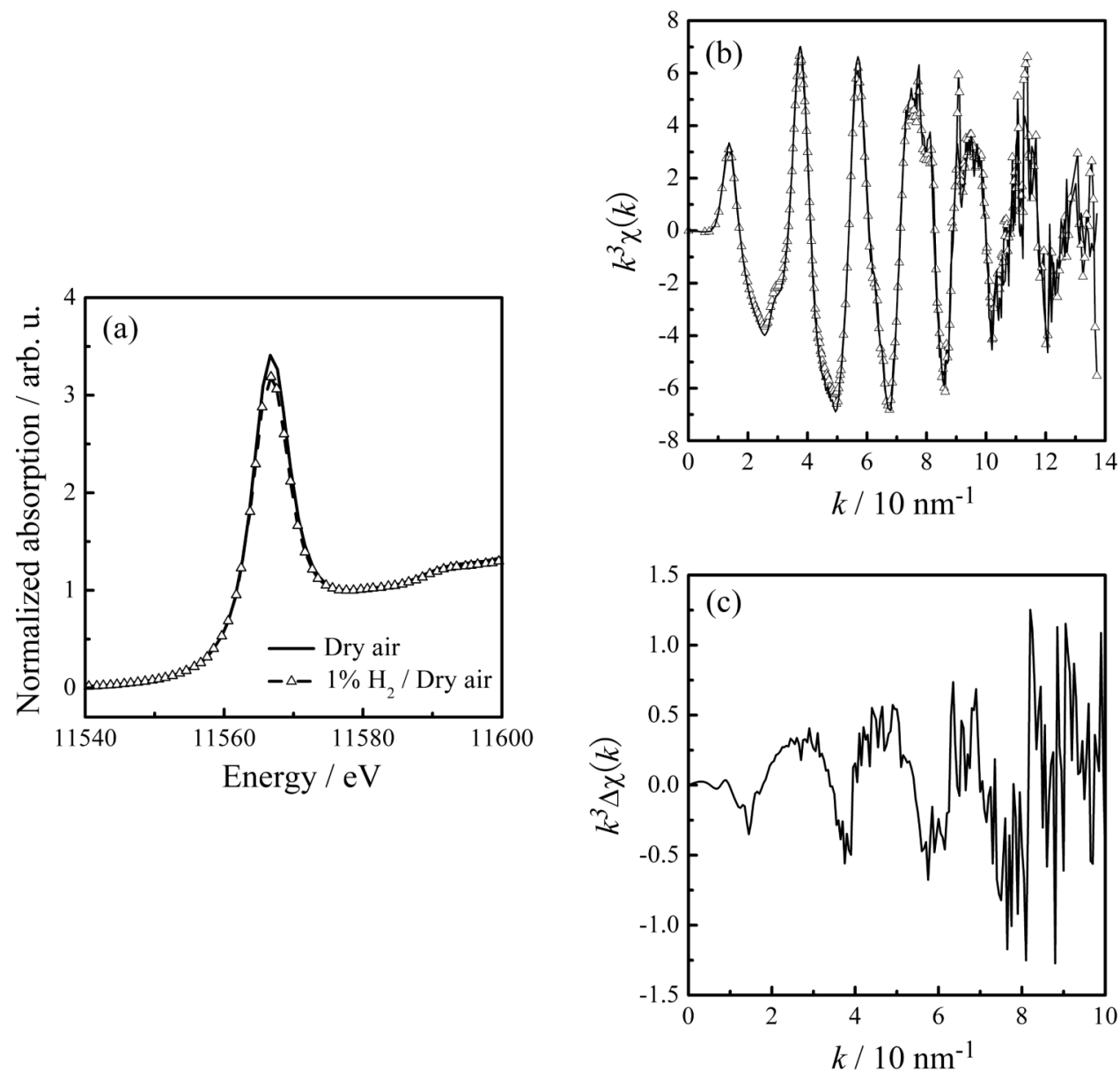

FIG. 6. Pt $\mathrm{L}_{3}$-edge XANES (a) and EXAFS (b) spectra to $703 \mathrm{~K}$ under a flow of dry air (solid line) and $1 \% \mathrm{H}_{2}$-containing air (triangle with broken line). (a) XANES spectra, (b) $\mathrm{k}^{3}$-weighted EXAFS oscillations, and (c) their difference spectrum $k^{3} \Delta \chi(k)$.

large half cone angle ${ }^{1}$ of $56^{\circ}$ by minimizing the sample heater size $\left(25 \times 35 \mathrm{~mm}^{2}\right)$. This cell also has no water-cooling system because the Kapton window temperature was kept at less than $373 \mathrm{~K}$ due to the high thermal conductivity of $\mathrm{Al}$, even at a

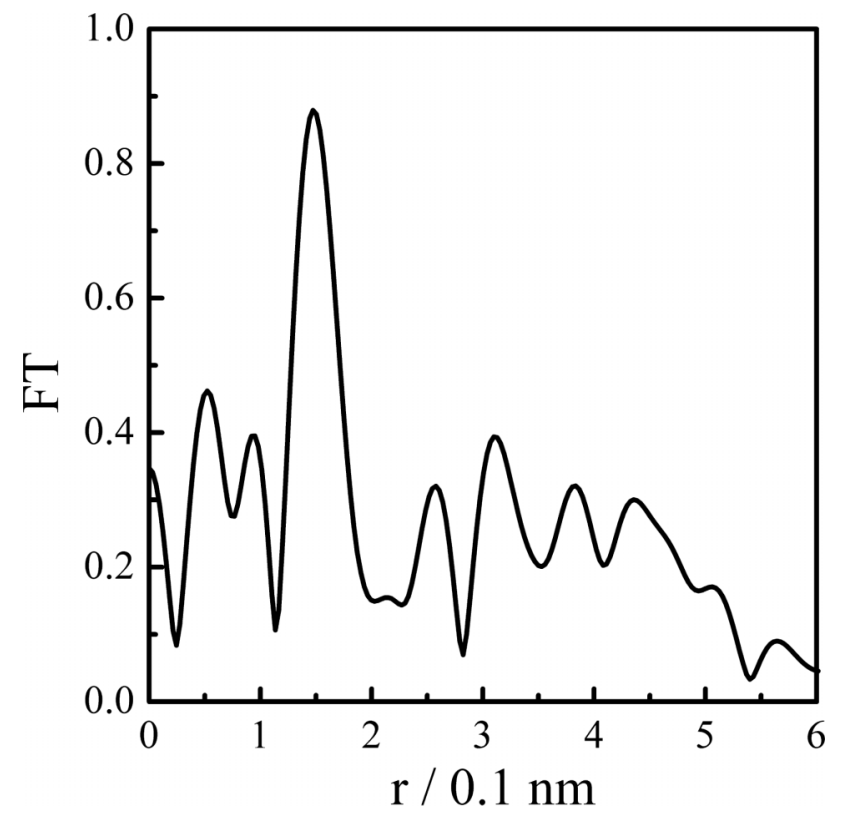

FIG. 7. Fourier transform of the difference spectrum $k^{3} \Delta \chi(k)$.

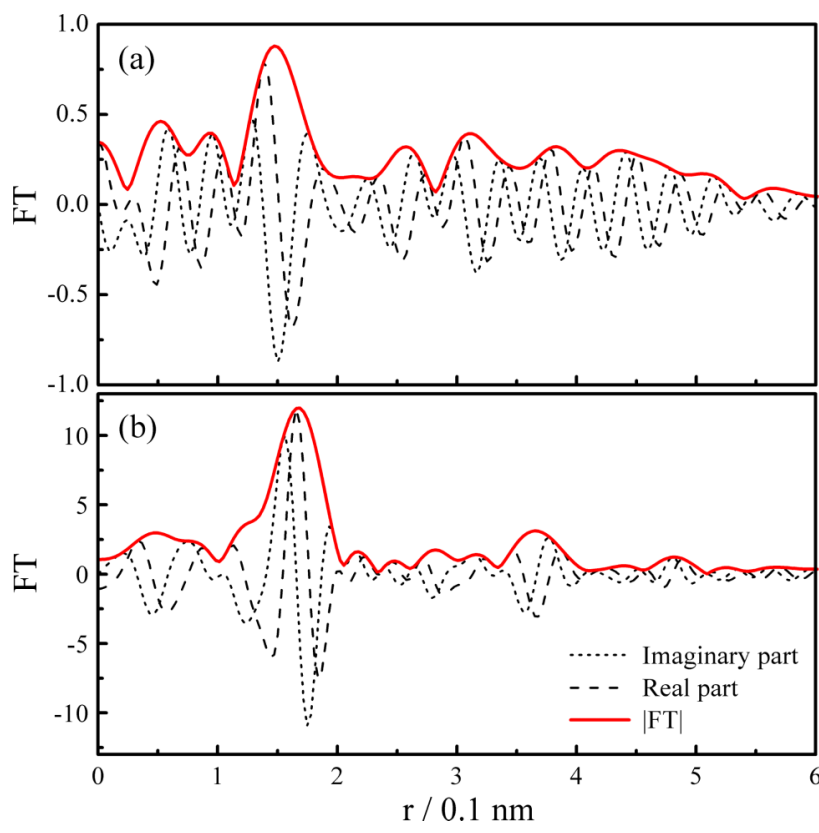

FIG. 8. The Fourier transforms. (a) The difference spectrum $k^{3} \Delta \chi(k)$. (b) Dry air at $703 \mathrm{~K}$. Dotted, broken, and solid red lines indicated imaginary, real, and absolute parts, respectively. 
sample temperature of $703 \mathrm{~K}$. The system can be applied to reaction analysis of solid oxide, bimetallic catalyst for fuel cells, ${ }^{19-22}$ and in situ analysis of W oxide photo/electrochromic materials. ${ }^{54,55}$ These powder samples are loaded into a small container made of BN or graphite and fixed to the heater. The cell is thus universally applicable to many systems in the measurements of fluorescence XAFS under the reaction conditions.

\section{CONCLUSIONS}

We have developed a new type of in situ fluorescence XAFS cell, which has a large solid angle, a half-cone angle of $56^{\circ}$, and no water-cooling system. The sample is locally heated using a small heater, which prevents the unwanted heating of system components other than the sample. We obtain a good $\mathrm{S} / \mathrm{N}$ ratio of in situ fluorescence XAFS signal under the reaction conditions, which allows data analysis by difference spectra to elucidate minute changes in XAFS oscillations during reactions.

\section{ACKNOWLEDGMENTS}

This research was performed with support from the "Next Generation High Reliability Gas Sensor Technical Development" project of the New Energy and Industrial Technology Developments Organization (NEDO). All XAFS measurements were performed in the Photon Factory, KEK as (PAC Nos. 2010G592 and 2012G680).

${ }^{1}$ J. Jaklevic, J. A. Kirby, M. P. Klein, A. S. Robertson, G. S. Brown, and P. Eisenberger, Solid State Commun. 23, 679 (1977).

${ }^{2}$ K. Asakura, Catalysis edited by J. J. Spivey and M. Gupta (RSC publishing, Cambridge, 2012), Vol. 281, p. 281.

${ }^{3}$ H. Oyanagi, A. Tsukada, M. Naito, N. L. Saini, M.-O. Lampert, D. Gutknecht, P. Dressler, S. Ogawa, K. Kasai, S. Mohamed, and A. Fukano, J. Synchrotron Radiat. 13, 314 (2006).

${ }^{4}$ F. W. Lytle, R. B. Greegor, D. R. Sandstrom, E. C. Marques, J. Wong, C. L. Spiro, G. P. Huffman, and F. E. Huggins, Nucl. Instrum. Methods Phys. Res., Sect. A 226, 542 (1984).

${ }^{5}$ O. V. Safonova, M. Tromp, J. A. Bokhoven, F. M. F. de Groot, J. Evans, and P. Glatzel, J. Phys. Chem. B 110, 16162 (2006).

${ }^{6}$ M. Hübner, D. Koziej, M. Bauer, N. Barsan, K. Kvashnina, M. D. Rossell, U. Weimar, and J.-D. Grunwaldt, Angew. Chem., Int. Ed. 50, 2841 (2011).

${ }^{7}$ Z. Zhong, L. D. Chapman, B. A. Bunker, G. B. Bunker, R. Fischetti, and C. U. Segre, J. Synchrotron Radiat. 6, 212 (1999).

${ }^{8}$ N. G. Kujala, C. Karanfil, and R. A. Barrea, Rev. Sci. Instrum. 82, 063106 (2011).

${ }^{9}$ H. Uehara, Y. Uemura, T. Ogawa, K. Kono, R. Ueno, Y. Niwa, H. Nitani, H. Abe, S. Takakusagi, M. Nomura, Y. Iwasawa, and K. Asakura, Phys. Chem. Chem. Phys. 16, 13748 (2014).

${ }^{10}$ X-ray Absorption Fine Structure for Catalysts and Surfaces, edited by Y. Iwasawa (World Scientific, Singapore, 1996).

${ }^{11}$ P. Kappen, L. Tröger, G. Materlik, C. Reckleben, K. Hansen, J.-D. Grunwaldt, and B. S. Clausen, J. Synchrotron Radiat. 9, 246 (2002).

${ }^{12}$ J.-D. Grunwaldt, P. Kappen, L. Basini, and B. S. Clausen, Catal. Lett. 78, 13 (2002).

${ }^{13}$ T. Kubota, N. Hosomi, K. K. Bando, T. Matsui, and Y. Okamoto, Phys. Chem. Chem. Phys. 5, 4510 (2003).

${ }^{14}$ S. R. Bare, G. E. Mickelson, F. S. Modica, A. Z. Ringwelski, and N. Yang, Rev. Sci. Instrum. 77, 023105 (2006).

${ }^{15}$ N. Weiher, E. Bus, B. Gorzolnik, M. Möller, R. Prins, and J. A. van Bokhoven, J. Synchrotron Radiat. 12, 675 (2005).

${ }^{16}$ C. L. Fontaine, L. Barthe, A. Rochet, and V. Briois, Catal. Today 205, 148 (2013).
${ }^{17}$ D. Koziej, M. Hübner, N. Barsan, U. Weimer, M. Sikora, and J.-D. Grunwaldt, Phys. Chem. Chem. Phys. 11, 8620 (2009).

${ }^{18}$ M. Hübner, D. Koziej, J.-D. Grunwaldt, U. Weimar, and N. Barsan, Phys. Chem. Chem. Phys. 14, 13249 (2012).

${ }^{19}$ A. Gurlo and R. Riedel, Angew. Chem., Int. Ed. 46, 3826 (2007).

${ }^{20}$ A. Gurlo and R. Riedel, ChemPhysChem 11, 79 (2010).

${ }^{21}$ M. Gaidi, M. Labeau, B. Chenevier, and J. L. Hazemann, Sens. Actuators, B 48, 277 (1998).

${ }^{22}$ S. Mukerjee and R. C. Urian, Electrochim. Acta 47, 3219 (2002).

${ }^{23}$ R. J. K. Wiltshire, C. R. King, A. Rose, P. P. Wells, M. P. Hogarth, D. Thompsett, and A. E. Russell, Electrochim. Acta 50, 5208 (2005).

${ }^{24}$ J.-D. Grunwaldt and C. G. Schroer, Chem. Soc. Rev. 39, 4741 (2010).

${ }^{25}$ N. Ishiguro, S. Kityakarn, O. Sekizawa, T. Uruga, T. Sasabe, K. Nagasawa, T. Yokoyama, and M. Tada, J. Phys. Chem. C 118, 15874 (2014).

${ }^{26}$ M. R. Antonio, L. Soderholm, and I. Song, J. Appl. Electrochem. 27, 784 (1997).

${ }^{27}$ M. Balasubramanian, C. A. Melendres, and A. N. Mansour, Thin Solid Films 347, 178 (1999).

${ }^{28}$ S. Modiano, J. A. V. Carreno, C. S. Fujivara, R. M. Torresi, V. Vivier, A. V. Benedetti, and O. R. Mattos, Electrochim. Acta 53, 3670 (2008).

${ }^{29}$ J. Monnier, S. Reguer, E. Foy, D. Testemale, F. Mirambet, M. Saheb, P. Dillmann, and I. Guillot, Corros. Sci. 78, 293 (2014).

${ }^{30} \mathrm{~T}$. Suzuki, K. Onodera, F. Inoue, and K. Tsuda, Japan patent JP3812215, (2006).

${ }^{31}$ T. Suzuki, K. Onodera, F. Inoue, and K. Tsuda, Japan patent JP4376093, (2009).

${ }^{32}$ T. Suzuki, K. Kunihara, M. Kobayashi, S. Tabata, K. Higaki, and H. Ohnishi, Sens. Actuators, B 109, 185 (2005).

${ }^{33}$ S. Tabata, K. Higaki, H. Ohnishi, T. Suzuki, K. Kunihara, and M. Kobayashi, Sens. Actuators, B 109, 190 (2005).

${ }^{34}$ N. Murata, T. Suzuki, M. Kobayashi, F. Togoh, and K. Asakura, Phys. Chem. Chem. Phys. 15, 17938 (2013).

${ }^{35}$ N. Yamazoe, Y. Kurokawa, and T. Seiyama, Sens. Actuators 4, 283 (1983).

${ }^{36}$ A. V. Tadeev, G. Delabouglise, and M. Labeau, Mater. Sci. Eng.: B 57, 76 (1998).

${ }^{37}$ K. Asakura, H. Nagahiro, N. Ichikuni, and Y. Iwasawa, Appl. Catal., A 188, 313 (1999).

${ }^{38}$ M. Gaidi, J. L. Hazemann, I. Matko, B. Chenevier, M. Rumyantseva, A. Gaskov, and M. Labeau, J. Electrochem. Soc. 147, 3131 (2000).

${ }^{39}$ F. W. Lytle, G. H. Via, and J. H. Sinfelt, J. Chem. Phys. 67, 3831 (1977).

${ }^{40}$ K. Asakura and Y. Iwasawa, J. Phys. Chem. 93, 4213 (1989).

${ }^{41}$ K. Asakura, K. K. Bando, K. Isobe, H. Arakawa, and Y. Iwasawa, J. Am. Chem. Soc. 112, 3242 (1990).

${ }^{42}$ K. Asakura, K. K. Bando, Y. Iwasawa, H. Arakawa, and K. Isobe, J. Am. Chem. Soc. 112, 9096 (1990).

${ }^{43}$ B. S. Clausen, J. Schiotz, L. Grabaek, C. V. Ovesen, K. W. Jaconsen, J. K. Norskov, and H. Topsoe, Top. Catal. 1, 367 (1994).

${ }^{44}$ A. Suzuki, Y. Inada, A. Yamaguchi, T. Chihara, M. Yuasa, M. Nomura, and Y. Iwasawa, Angew. Chem., Int. Ed. 42, 4795 (2003).

${ }^{45}$ H. Tanaka, M. Uenishi, M. Taniguchi, I. Tan, K. Narita, M. Kimura, K. Kaneko, Y. Nishihata, and J. Mizuki, Catal. Today 117, 321 (2006).

${ }^{46}$ T. Kawai, K. K. Bando, Y.-K. Lee, S. T. Oyama, W.-J. Chun, and K. Asakura, J. Catal. 241, 20 (2006).

${ }^{47}$ M. Nomura, J. Synchrotron Radiat. 5, 851 (1998).

${ }^{48} \mathrm{M}$. Nomura and A. Koyama, "Design and performance of a new XAFS beamline at the photon factory; BL12C," KEK Report, Photon Factory, 95-15, 1996.

${ }^{49} \mathrm{~K}$. Asakura, "Analysis of EXAFS," in X-ray Absorption Fine Structure for Catalysts and Surfaces, edited by Y. Iwasawa (World Scientific, Singapore, 1996), p. 33.

${ }^{50}$ T. Taguchi, AIP Conf. Proc. 882, 162 (2007).

${ }^{51} \mathrm{~K}$. Asakura, Polarization-Dependent Total Reflection Fluorescence Extended X-ray Absorption Fine Structure and its Application to Supported Catalysis, Catalysis Book Series edited by J. G. Catalano (RSC publishing, 2012), p. 281.

${ }^{52}$ M. Ippommatsu, H. Ohnishi, H. Sasaki, and T. Matsumoto, J. Appl. Phys. 69, 836 (1991).

${ }^{53}$ J. C. J. Bart, Adv. Catal. 34, 203 (1986).

${ }^{54}$ R. Kiebach, N. Pienack, W. Bensch, J.-D. Grunwaldt, A. Michailovski, A. Baiker, T. Fox, Y. Zhou, and G. R. Patzke, Chem. Mater. 20, 3022 (2008)

${ }^{55}$ M. Deepa, P. Singh, S. N. Sharma, and S. A. Agnihotry, Sol. Energy Mater. Sol. Cells 90, 2665 (2006). 